\title{
Fermentative hydrogen production from corn stover hydrolyzate by two typical seed sludges: Effect of temperature
}

\author{
Kun Zhang ${ }^{a}$, Nan-Qi Ren ${ }^{b, *}$, Ai-Jie Wang ${ }^{b, c}$ \\ a College of Power and Energy Engineering, Harbin Engineering University, Harbin 150001, China \\ b State Key Lab of Urban Water Resource and Environment, Harbin Institute of Technology, Harbin 150090, China \\ ${ }^{c}$ Research Center for Eco-Environmental Sciences, Chinese Academy of Sciences, Beijing 100085, China
}

\section{A R T I C L E I N F O}

Article history:

Received 10 November 2014

Received in revised form

13 January 2015

Accepted 21 January 2015

Available online 11 February 2015

Keywords:

Biohydrogen

Temperature

Seed sludge

Corn stover hydrolyzate

Denaturing gradient gel electropho-

resis (DGGE)

Microbial diversity analysis

\begin{abstract}
A B S T R A C T
The temperature effect on fermentative hydrogen $\left(\mathrm{H}_{2}\right)$ production from corn stover hydrolyzate was investigated under mesophilic (37 and $30{ }^{\circ} \mathrm{C}$ ), thermophilic $\left(55^{\circ} \mathrm{C}\right.$ ), and extreme thermophilic $\left(70^{\circ} \mathrm{C}\right)$ conditions by using two typical seed sludges (activated sludge and anaerobic granular sludge). Among various temperatures, the fermentation at $55{ }^{\circ} \mathrm{C}$ reached the optimal $\mathrm{H}_{2}$ production with the values of $6.08 \mathrm{mmol}-\mathrm{H}_{2} / \mathrm{g}$-utilized sugar for activated sludge and $7.74 \mathrm{mmol}-\mathrm{H}_{2} /$ g-utilized sugar for anaerobic granular sludge, respectively. For the two seed sludges, the effectiveness of fermentation temperature on $\mathrm{H}_{2}$ production both followed the order as $55^{\circ} \mathrm{C}>70^{\circ} \mathrm{C}>37^{\circ} \mathrm{C} \approx 30^{\circ} \mathrm{C}$. The soluble metabolites composition at $55^{\circ} \mathrm{C}$ showed the highest acetate and butyrate concentrations, as well as the minimum ethanol production, coinciding with better $\mathrm{H}_{2}$-producing performances in these cases. Microbial community analysis indicated that microbial community diversity significantly decreased with increased fermentation temperature. Facultative anaerobes, such as Enterobacter spp., Klebsiella spp., and Citrobacter spp., were dominant in microbial community of the two seed sludges. As efficient $\mathrm{H}_{2}$ producers, Bacillus sp. AB5283 in activated sludge and Thermoanaerobacterium sp. PO-2009 in anaerobic granular sludge might be mainly responsible for high $\mathrm{H}_{2}$ yields under thermophilic condition.
\end{abstract}

Copyright $\odot$ 2015, Hydrogen Energy Publications, LLC. Published by Elsevier Ltd. All rights

reserved.

\section{Introduction}

Due to the depletion of fossil fuels and the aggravation of environmental pollutions, the development of clean and renewable energy sources has become an important part of fundamental energy strategy in many countries [1,2]. Among various novel energy vectors, hydrogen $\left(\mathrm{H}_{2}\right)$ attracts much attention due to its high energy content (142 kJ/g), nonpolluting nature (carbon dioxide-neutral and no gaseous pollutants emission), and versatility in many fields (direct combustion, gas engine, electricity production by fuel cells, etc.) [3]. Traditionally, $\mathrm{H}_{2}$ is industrially produced by energy intensive processes, such as steam reforming of natural gas, gasification of coal, and water electrolysis [4]. In recent years, dark fermentative $\mathrm{H}_{2}$ production has become a promising

\footnotetext{
* Corresponding author. Tel./fax: +86 45186282008.

E-mail address: rnq@hit.edu.cn (N.-Q. Ren). 
method for sustainable practical applications owing to simple reactor configuration, mild operation conditions, and high $\mathrm{H}_{2}$ production rate [5]. More importantly, $\mathrm{H}_{2}$ production by dark fermentation can be achieved by using various organic waste materials in an eco-friendly way, by which $\mathrm{H}_{2}$ production cost can be significantly decreased to make it economically feasible at a commercial scale [6].

To explore suitable substrates for $\mathrm{H}_{2}$ production, many kinds of organic wastes have been examined for their $\mathrm{H}_{2}$ producing potentials, such as sugar-rich feedstock [7], kitchen wastes [8], biodiesel and oil residuals [9], and lignocellulosic material [10]. Among these wastes, lignocellulosic material is one of the most promising substrates by virtue of the fact that they are abundant, easily available, and low-cost $[11,12]$. In order to decompose the harsh microstructure of lignocellulosic feedstock to make it more microbially accessible, lignocellulosic hydrolyzate is commonly generated and recognized as an applicable utilization form. However, due to its complex composition with various monosaccharides and byproducts, $\mathrm{H}_{2}$ yields are found to be relatively low [13]. For the purpose of improving $\mathrm{H}_{2}$ yield by using lignocellulosic hydrolyzate, some researchers pay more attention to optimizing fermentation conditions for mixed anaerobic microflora, such as nutrient, temperature, and $\mathrm{pH}$ [14-16]. By doing this, effective $\mathrm{H}_{2}$-producing microbes capable of decomposing complex organic compounds are expected to be predominant in microbial community, leading to better performances on $\mathrm{H}_{2}$ production and substrate utilization efficiency.

Among various parameters, temperature is a vital factor for dark fermentative $\mathrm{H}_{2}$ production, affecting growth rates and metabolic activities of $\mathrm{H}_{2}$-producing microbes [17]. Generally, fermentative $\mathrm{H}_{2}$ production can be maintained at mesophilic $\left(25-40{ }^{\circ} \mathrm{C}\right)$, thermophilic $\left(40-65^{\circ} \mathrm{C}\right)$, and extreme thermophilic $\left(65-80^{\circ} \mathrm{C}\right)$ conditions [18]. For a long time, mesophilic conditions have been commonly adopted for fermentative $\mathrm{H}_{2}$ production. Recently, thermophilic and extreme thermophilic conditions attract much attention for $\mathrm{H}_{2}$ production because of several advantages, such as efficient utilization of complex substrates, better thermodynamic conditions, and suppression of methanogens [19]. Moreover, the predominance of some efficient $\mathrm{H}_{2}$-producing thermophiles, such as Thermoanaerobacterium spp., is considered as key microbial factor responsible for better performances in these cases [20]. Till now, some studies have been conducted to comparing temperature effects on $\mathrm{H}_{2}$ production by using various wastes, such as palm oil mill effluent [21], Laminaria japonica [22], and feedlot cattle manure [23], but few studies are reported to explore preferable temperature with lignocellulosic materials as the substrate [24,25]. In addition, due to different fermentation patterns and bacterial community structures in these studies, we can hardly make clear the inherent relationships among fermentation temperature, $\mathrm{H}_{2}$ producing performance, and microbial community characteristics.

In this study, two commonly-used seed sludges, i.e., activated sludge from a municipal treatment plant and anaerobic granular sludge from an anaerobic bioreactor, were used as touchstones to investigate the effect of temperature on dark fermentative $\mathrm{H}_{2}$ production and microbial community structure. With corn stover hydrolyzate as the substrate, fermentation tests were kept at mesophilic (37 and $30{ }^{\circ} \mathrm{C}$ ), thermophilic $\left(55^{\circ} \mathrm{C}\right)$, and extreme thermophilic $\left(70^{\circ} \mathrm{C}\right)$ conditions, respectively. Biogas and $\mathrm{H}_{2}$ production were measured to address $\mathrm{H}_{2}$-producing behavior, by which kinetic analysis was carried out using the modified Gompertz equation. Soluble metabolites were investigated to reveal relationships between $\mathrm{H}_{2}$ production and distribution of liquid end products. Microbial community structure was analyzed by using polymerase chain reaction-denaturing gradient gel electrophoresis (PCR-DGGE) and corresponding biodiversity analysis.

\section{Materials and methods}

\section{Raw materials and the hydrolysis process}

Corn stover feedstock was obtained from the suburb of Harbin city, Heilongjiang Province, China. The raw corn stover was thoroughly washed with clean tap water to remove impurities and naturally desiccated at room temperature. Subsequently, dried corn stover was grinded to a particle size of $0.2-0.4 \mathrm{~mm}$ by using a tissue crusher (SZ-1100B-3, Shangzu, China). The main composition of the corn stover powder contained $38.7 \%$ glucan, $20.3 \%$ xylan, $18.2 \%$ lignin and $4.2 \%$ ash. For the following acid hydrolysis process, the corn stover powder was put into $1.7 \%(\mathrm{v} / \mathrm{v}) \mathrm{H}_{2} \mathrm{SO}_{4}$ solution with a solid/liquid ratio of 1:50 $(w / v)$. The hydrolysis time and temperature were kept at $120 \mathrm{~min}$ and $121^{\circ} \mathrm{C}$, respectively. After the hydrolysis process, solid residues of the suspension were removed by centrifugation at 12,000 r/min for $5 \mathrm{~min}$. By adjusting the supernatant to $\mathrm{pH} 7.0$ with $1 \mathrm{~mol} / \mathrm{L} \mathrm{NaOH}$ solution, corn stover hydrolyzate was generated with the reducing sugar concentration of about $6.2 \mathrm{~g} / \mathrm{L}$. The raw corn stover hydrolyzate was then prepared for the following anaerobic fermentation.

\section{Seed sludge and batch test}

Two typical seed sludges were used in this study, namely, activated sludge from an aeration tank of Wenchang wastewater treatment plant, and anaerobic granular sludge from a bench-scale expanded granular sludge bed reactor (EGSB) treating starch wastewater. For revealing the effect of temperature on original microbial community truthfully, commonly-used pretreatment methods (such as boiling) were not carried out on the two seed sludges. After the removal of impurities by using sieves, the $\mathrm{pH}$, total suspended solid (TSS) and volatile suspended solid (VSS) concentrations were 6.86, $5.77 \mathrm{~g} / \mathrm{L}$, and $4.21 \mathrm{~g} / \mathrm{L}$ for activated sludge, and 7.58, $39.3 \mathrm{~g} / \mathrm{L}$, and $28.9 \mathrm{~g} / \mathrm{L}$ for anaerobic granular sludge, respectively. For the following fermentation tests, the inoculation dosage was about $4 \%(v / v)$ by using diluted seed sludges, and the microbial concentrations in medium were about $0.16 \mathrm{~g}$-VSS/L for activated sludge inoculation and about $0.96 \mathrm{~g}$-VSS/L for anaerobic granular sludge inoculation, respectively.

Fermentation tests were carried out anaerobically in $100 \mathrm{~mL}$ serum vials at a working medium volume of $50 \mathrm{~mL}$. For all the tests, the medium contained $5.0 \mathrm{~g} / \mathrm{L}$ sugars diluted from corn stover hydrolyzate (about $3.8 \mathrm{~g} / \mathrm{L}$ xylose, $0.9 \mathrm{~g} / \mathrm{L}$ glucose, $0.2 \mathrm{~g} / \mathrm{L}$ arabinose, and $0.1 \mathrm{~g} / \mathrm{L}$ other sugars), and supplemented 
by following nutrients (per liter): $2.2 \mathrm{~g} \mathrm{~K}_{2} \mathrm{HPO}_{4} \cdot 3 \mathrm{H}_{2} \mathrm{O}, 1.0 \mathrm{~g}$ $\left(\mathrm{NH}_{4}\right)_{2} \mathrm{SO}_{4}, 1.0 \mathrm{~g} \mathrm{NaCl}, 0.75 \mathrm{~g} \mathrm{KH}_{2} \mathrm{PO}_{4}, 0.5 \mathrm{~g} \mathrm{MgCl}{ }_{2} \cdot 6 \mathrm{H}_{2} \mathrm{O}, 0.5 \mathrm{~g}$ cysteine- $\mathrm{HCl}, 0.2 \mathrm{~g} \mathrm{KCl}, 2.0 \mathrm{~g}$ yeast extract, $5 \mathrm{~mL}$ vitamin solution, and $0.5 \mathrm{~mL}$ trace element solution, with $\mathrm{pH}$ adjusted to 7.0. The components of the vitamin solution were (per liter): $350 \mathrm{mg}$ nicotinic acid, $100 \mathrm{mg}$ pyridoxine hydrochloride, $50 \mathrm{mg}$ lipoic acid, $50 \mathrm{mg}$ para-aminobenzoic acid, $50 \mathrm{mg}$ calcium pantothenate, $20 \mathrm{mg}$ biotin, $20 \mathrm{mg}$ folic acid, $5 \mathrm{mg}$ thiamine hydrochloride, and $1 \mathrm{mg}$ vitamin B12. The trace element solution contained (per liter) $1.5 \mathrm{~g} \mathrm{FeCl}_{2}, 190 \mathrm{mg} \mathrm{CoCl} \cdot 6 \mathrm{H}_{2} \mathrm{O}$, $100 \mathrm{mg} \mathrm{MnCl} 2 \cdot 4 \mathrm{H}_{2} \mathrm{O}, 70 \mathrm{mg} \mathrm{ZnCl}, 36 \mathrm{mg} \mathrm{Na}{ }_{2} \mathrm{MoO}_{4} \cdot \mathrm{H}_{2} \mathrm{O}, 24 \mathrm{mg}$ $\mathrm{NiCl}_{2} \cdot 6 \mathrm{H}_{2} \mathrm{O}, 15 \mathrm{mg} \mathrm{Na} \mathrm{SeO}_{4} \cdot 5 \mathrm{H}_{2} \mathrm{O}, 15 \mathrm{mg} \mathrm{Na}{ }_{2} \mathrm{WO}_{4}, 6 \mathrm{mg} \mathrm{H}_{3} \mathrm{BO}_{3}$, and $2 \mathrm{mg} \mathrm{CuCl}{ }_{2} \cdot 2 \mathrm{H}_{2} \mathrm{O}$.

After nitrogen gas sparging to remove oxygen in headspace, serum vials capped with rubber stoppers were separately incubated at $30{ }^{\circ} \mathrm{C}$ and $37^{\circ} \mathrm{C}$ in two air-bath orbital shakers (HZQ-C, Donglian, China), and $55^{\circ} \mathrm{C}$ and $70{ }^{\circ} \mathrm{C}$ in two water-bath orbital shakers (HZS-HA, Donglian, China) respectively at a rotation speed of $120 \mathrm{r} / \mathrm{min}$. All the tests were repeated three times to ensure the data reproducibility.

\section{Chemical analysis}

Total sugar contents were measured by traditional phenolsulfuric method [26]. Cell density was measured by using a spectrophotometer (UV-2102C, Unico, USA) at $600 \mathrm{~nm}$. Biogas accumulation was measured at each time interval $(4 \mathrm{~h})$ by the plunger displacement method [27]. Contents of $\mathrm{H}_{2}$ and carbon dioxide in biogas were determined by a gas chromatography (SC2, Shanghai Analytical Apparatus, China) equipped with a thermal conductivity detector. At the end of the fermentation, concentrations of volatile fatty acids (VFAs) and alcohol in fermentation liquor were analyzed by using another gas chromatography (4890D, Agilent Cooperation, USA) with a flame ionization detector.

\section{Microbial community analysis}

PCR-DGGE protocol was employed in this study to investigate microbial community structure. The extraction of total bacterial genomic DNA was described in our previous study [28]. The universal primer set of BSF968GC (5' CGCCCGCCGCGCG CGGCGGGCGGGGCGGGGGCACGGGGGGAACGCGAA-

GAACCTTAC $3^{\prime}$ ) and BSR1401 (5' CCCCGTCAATTCCTTTGAGTTT 3') [29] were used to amplify the V6-V8 region of bacterial 16S rRNA gene. PCR amplification was carried out in an automated thermal cycler (GeneAmp PCR System 9700, Applied Biosystems, USA) using the following protocol: initial denaturation at $94{ }^{\circ} \mathrm{C}$ for $5 \mathrm{~min}$; 35 cycles of denaturation at $94{ }^{\circ} \mathrm{C}$ for $40 \mathrm{~s}$, annealing at $94^{\circ} \mathrm{C}$ for $40 \mathrm{~s}$ (decreasing $0.1^{\circ} \mathrm{C}$ per cycle to $51.5^{\circ} \mathrm{C}$ ), and extension at $72^{\circ} \mathrm{C}$ for $30 \mathrm{~s}$; followed by a final extension at $72^{\circ} \mathrm{C}$ for $7 \mathrm{~min}$.

DGGE analysis was achieved by using a Universal Mutation Detection System (Dcode ${ }^{\mathrm{TM}}$, BioRad, USA). The PCR products were loaded to $6 \%$ polyacrylamide gel with $30 \%-60 \%$ denaturant gradients, and the electrophoresis was run at $60{ }^{\circ} \mathrm{C}$ and $120 \mathrm{~V}$ for $6 \mathrm{~h}$. After the electrophoresis, the gel was stained with $0.1 \% \mathrm{AgNO}_{3}$ solution for $30 \mathrm{~min}$ and visualized with an image scanner (PowerLook 1000, Umax, China). For DGGE profiles, band intensity was digitally recognized by using the
Quantity One ${ }^{\mathrm{TM}}$ software (Biorad, USA), by which number of bands, Shannon-Wiener diversity index, Simpson diversity index, and Pielou evenness index were calculated as described by Zouache and colleagues [30] to address microbial community characteristics in each sample. After the visual capture of DGGE profiles, DNA templates in predominant DGGE bands were extracted, re-amplified and then sequenced by commercial service (Huada, China). The homology for the sequencing results was compared with available sequences in the GenBank database using the BLAST algorithm.

\section{Kinetic analysis}

The cumulative $\mathrm{H}_{2}$ production in all tests was kinetically fitted by the modified Gompertz equation as previously described [31], and the equation is as follows:

$H=P \cdot \exp \left\{-\exp \left[\frac{R_{m} \cdot e}{P}(\lambda-t)+1\right]\right\}$

where $H(\mathrm{~mL} / \mathrm{L})$ represents the cumulative $\mathrm{H}_{2}$ production, $P$ (mL/L) means the maximum $\mathrm{H}_{2}$ production, $\mathrm{R}_{\mathrm{m}}(\mathrm{mL} / \mathrm{h})$ represents the maximum $\mathrm{H}_{2}$ production rate, $\lambda(\mathrm{h})$ means the lagphase time, and $e$ is the constant of 2.71828. The values of $P$, $R_{\mathrm{m}}$, and $\lambda$ were calculated with exponential regression analysis by using the Origin 7.5 software.

\section{Results and discussion}

\section{Biogas and $\mathrm{H}_{2}$ production}

During the fermentation process by using corn stover hydrolyzate, biogas and $\mathrm{H}_{2}$ accumulations were measured with time till the biogas production was completely finished. For all batch tests, gaseous products were only $\mathrm{H}_{2}$ and carbon dioxide with no methane detection under different temperatures, suggesting that fermentation temperature was not the key factor suppressing the methanogenesis. In our view, methanogens might be incapable of utilizing refractory sugars in corn stover hydrolyzate and simultaneously inhibited by toxic byproducts in the hydrolyzate [32], resulted in the elimination of methanogens during the process. Fig. 1 indicates the time-course profiles of biogas and $\mathrm{H}_{2}$ production under different temperatures $\left(37,30,55\right.$, and $\left.70{ }^{\circ} \mathrm{C}\right)$. Fermentation temperature caused similar effects on biogas and $\mathrm{H}_{2}$-producing production. The optimum biogas and $\mathrm{H}_{2}$ yields were both achieved at $55{ }^{\circ} \mathrm{C}$ (activated sludge: $1258.3 \mathrm{~mL}$-biogas/L and $611.8 \mathrm{~mL}-\mathrm{H}_{2} / \mathrm{L}$; anaerobic granular sludge: $1739.3 \mathrm{~mL}$-biogas/L

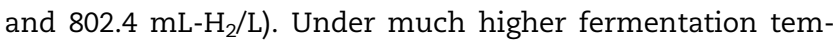
perature $\left(70^{\circ} \mathrm{C}\right)$, the biogas and $\mathrm{H}_{2}$ yields were remarkably less than those at $55^{\circ} \mathrm{C}$. For fermentation at $37^{\circ} \mathrm{C}$ and $30^{\circ} \mathrm{C}$, the biogas and $\mathrm{H}_{2}$ yields were similar and relatively low. Generally, for the two seed sludges, the effectiveness of fermentation temperature on $\mathrm{H}_{2}$ production followed the order as $55^{\circ} \mathrm{C}>70^{\circ} \mathrm{C}>37^{\circ} \mathrm{C} \approx 30^{\circ} \mathrm{C}$.

The experimental results indicate that with complex corn stover hydrolyzate as the substrate, fermentation at $55^{\circ} \mathrm{C}$ led to the optimum $\mathrm{H}_{2}$ yield for the two seed sludges, which was in accordance with previous studies. Kumar et al. [33] collected the seed sludge from a municipal wastewater 

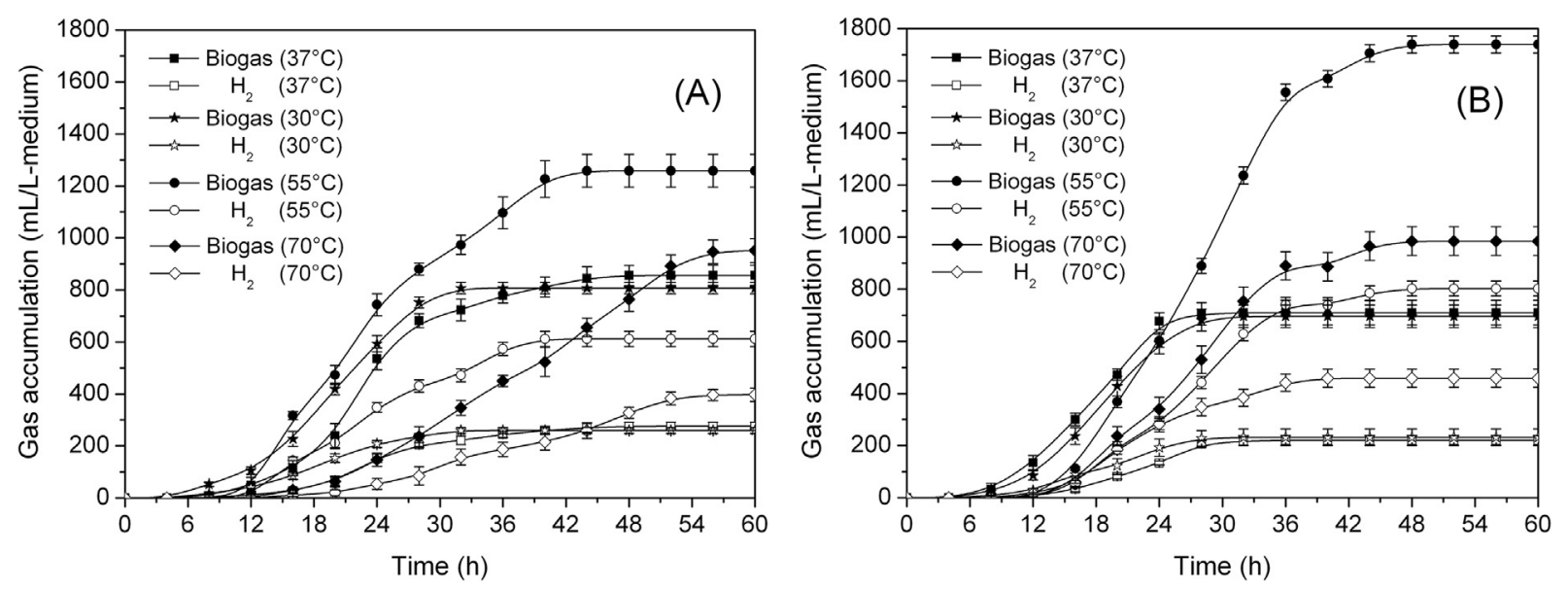

Fig. 1 - Time-course profiles of the biogas and $\mathrm{H}_{2}$ production under different fermentation temperatures. (A) activated sludge; (B) anaerobic granular sludge.

treatment. By using cellulosic materials-based de-oiled Jatropha waste, they concluded that the peak $\mathrm{H}_{2}$ production rate and $\mathrm{H}_{2}$ yield were both obtained at $55{ }^{\circ} \mathrm{C}$. Cakır et al. [24] obtained the seed sludge from acidogenic phase of an anaerobic wastewater treatment plant. With the inoculum pretreatment (boiling at $100^{\circ} \mathrm{C}$ for $1 \mathrm{~h}$ ) and the acclimation process $\left(55^{\circ} \mathrm{C}\right.$ for $3 \mathrm{~d})$ for the seed sludge, they found that dark fermentation of acid-hydrolyzed ground wheat was more beneficial under thermophilic condition $\left(55^{\circ} \mathrm{C}\right)$ than mesophilic condition $\left(37^{\circ} \mathrm{C}\right)$. Actually, by the inoculation of mesophilically and thermophilically digested sludge, thermophilic acidogenic sludge, cow waste slurry, etc., peak $\mathrm{H}_{2}$ yields can be commonly achieved under thermophilic environments $\left(55-60^{\circ} \mathrm{C}\right)$ with other complex wastes as the substrate $[34,35]$. In our view, better $\mathrm{H}_{2}$-producing performances under thermophilic conditions can be attributed to selective enrichment of some efficient $\mathrm{H}_{2}$-producing thermophiles, which are capable of producing more $\mathrm{H}_{2}$ by utilizing complex substrate components (to be illustrated in section 3.4).

In this study, extreme thermophilic condition $\left(70^{\circ} \mathrm{C}\right)$ led to relatively lower $\mathrm{H}_{2}$ production in comparison with thermophilic condition $\left(55^{\circ} \mathrm{C}\right)$. In some other studies, Kongjan et al. took anaerobic sludge from a continuous stirred tank reactor (working temperature of $70{ }^{\circ} \mathrm{C}$ ) as the inoculum, and they made repeated batch cultivations for the acclimation of the seed sludge [36]. Liu et al. obtained the seed sludge from $\mathrm{H}_{2}$ fermentation reactors using glucose and synthetic BA media under $70^{\circ} \mathrm{C}$ [37]. In these studies, high $\mathrm{H}_{2}$ yields were achieved under extreme thermophilic environment $\left(70{ }^{\circ} \mathrm{C}\right)$ with pentose and other wastes as the substrate, and the authors attributed the better $\mathrm{H}_{2}$-producing performance to preferable thermodynamic conditions, rapid substrate hydrolysis rate, and the enrichment of some special extreme thermophiles [38]. In our eyes, the unsatisfactory $\mathrm{H}_{2}$-producing performance under extreme thermophilic environment in this study might be mainly due to the fact that efficient $\mathrm{H}_{2}$-producing microbial community was not successfully founded in this case. Indigenous extreme thermophiles in the two seed sludges might be weak in utilizing complex substrate components, and negatively affected by some byproducts within corn stover hydrolyzate. For mesophilic conditions (37 and $30^{\circ} \mathrm{C}$ ), $\mathrm{H}_{2}$ yields were significantly low in this study, suggesting that mesophilic conditions might not be suitable for biohydrogen production by using lignocellulosic hydrolyzate.

As widely-used seed sludges for wastewater treatment and biogas production, the chosen activated sludge and anaerobic granular sludge in this study were representative to serve as ideal touchstones to evaluate the effect of fermentation temperature on $\mathrm{H}_{2}$ production from corn stover hydrolyzate. With $55^{\circ} \mathrm{C}$ as the optimal fermentation temperature for the two seed sludges, thermophilic condition corresponded to an enhanced $\mathrm{H}_{2}$ production from anaerobic granular sludge (3.6 times of that at $37^{\circ} \mathrm{C}$ ) than activated sludge (2.2 times of that at $\left.37^{\circ} \mathrm{C}\right)$. Under mesophilic conditions $\left(37\right.$ and $\left.30^{\circ} \mathrm{C}\right)$, activated sludge inoculation resulted in more $\mathrm{H}_{2}$ production than anaerobic granular sludge.

\section{Kinetic analysis}

Kinetic analysis was carried out for understanding $\mathrm{H}_{2}$-producing behavior under different fermentation temperatures. By using the modified Gompertz equation, we calculated important parameters, characterizing the $\mathrm{H}_{2}$ production processes (Table 1). With the values of $R^{2}$ all larger than 0.99 , the $\mathrm{H}_{2}$ accumulation trend of all batch tests could be adequately described by the equation. We found that the kinetic parameters were in accordance with $\mathrm{H}_{2}$-producing behaviors described in section 3.1. Concretely, for the two seed sludges, the optimum $\mathrm{H}_{2}$ production potential and maximum $\mathrm{H}_{2}$ production rate were both achieved at $55{ }^{\circ} \mathrm{C}$ (activated sludge: $627.4 \mathrm{~mL} / \mathrm{L}$ and $30.3 \mathrm{~mL} / \mathrm{h}$; anaerobic granular sludge: $821.8 \mathrm{~mL} / \mathrm{L}$ and $43.3 \mathrm{~mL} / \mathrm{h}$ ), indicating that the thermophilic conditions favored enhancement of $\mathrm{H}_{2}$ production while utilizing complex corn stover hydrolyzate. For lag-phase time, fermentation temperature at $30{ }^{\circ} \mathrm{C}$ corresponded to the shortest lag-phase time among the various temperatures tested (activated sludge: $10.7 \mathrm{~h}$; anaerobic granular sludge: $11.0 \mathrm{~h}$ ), suggesting that indigenous microbes can rapidly adapted to the complex components of corn stover hydrolyzate for $\mathrm{H}_{2}$ production. For much higher fermentation 
Table 1 - Kinetic parameters for $\mathbf{H}_{2}$ production under different fermentation temperatures.

\begin{tabular}{|c|c|c|c|c|c|}
\hline Seed sludge & Temperature $\left({ }^{\circ} \mathrm{C}\right)$ & $P(\mathrm{~mL} / \mathrm{L})$ & $R_{\mathrm{m}}(\mathrm{mL} / \mathrm{h})$ & $\lambda(\mathrm{h})$ & $R^{2}$ \\
\hline \multirow[t]{4}{*}{ Activated sludge } & 37 & $275.8 \pm 3.3$ & $16.5 \pm 0.9$ & $15.3 \pm 0.5$ & 0.997 \\
\hline & 30 & $263.4 \pm 2.7$ & $17.4 \pm 1.0$ & $10.7 \pm 0.5$ & 0.996 \\
\hline & 55 & $627.4 \pm 10.8$ & $30.3 \pm 2.0$ & $12.6 \pm 0.7$ & 0.994 \\
\hline & 70 & $506.6 \pm 37.1$ & $12.5 \pm 0.7$ & $21.3 \pm 0.9$ & 0.993 \\
\hline \multirow[t]{4}{*}{ Anaerobic granular sludge } & 37 & $223.6 \pm 3.3$ & $18.2 \pm 1.7$ & $15.4 \pm 0.6$ & 0.993 \\
\hline & 30 & $235.4 \pm 3.3$ & $16.7 \pm 1.4$ & $11.0 \pm 0.6$ & 0.993 \\
\hline & 55 & $821.8 \pm 13.9$ & $43.3 \pm 2.9$ & $16.6 \pm 0.6$ & 0.995 \\
\hline & 70 & $463.1 \pm 4.2$ & $28.0 \pm 1.3$ & $13.8 \pm 0.4$ & 0.998 \\
\hline
\end{tabular}

Values represent average \pm standard deviation. P: maximum $\mathrm{H}_{2}$ production; $R_{\mathrm{m}}$ : maximum $\mathrm{H}_{2}$ production rate; $\lambda$ : lag time.

temperatures $\left(37^{\circ} \mathrm{C}, 55^{\circ} \mathrm{C}\right.$, and $\left.70^{\circ} \mathrm{C}\right)$, long lag-phase time was necessary for indigenous microbes to acclimate the fermentation conditions prior to substrate utilization and biohydrogen production.

\section{Soluble metabolites profiles}

Fermentative processes with $\mathrm{H}_{2}$ production are always associated with the generation of VFAs and alcohols, and these soluble metabolites are interrelated with $\mathrm{H}_{2}$ formation on the basis of NADH balance [39]. At the end of the fermentation, we measured the concentrations of various liquid end products, including ethanol, acetate, propionate, butyrate, and formate (Fig. 2). Soluble metabolites profiles for each batch test performed a wide spectrum of various organic acids and ethanol, which might be the result of decomposing complex components within corn stover hydrolyzate. The hydrolysis process of corn stover produces many kinds of monosaccharide (glucose, xylose, arabinose etc.) and byproducts such as furan derivatives and phenolic compounds [40]. While utilizing these compounds, various metabolic pathways might be induced and result in multiple soluble metabolites [41]. At the same temperature, soluble metabolites profiles were similar for the two seed sludges, which might be attributed to similar microbial composition at the end of the fermentation (to be illustrated in section 3.4), which performed similar utilization patterns towards corn stover hydrolyzate.

For the two seed sludges, the fermentation temperature surely changed the distribution of soluble metabolites profiles. The fermentation process at $55^{\circ} \mathrm{C}$ corresponded to the highest acetate and butyrate concentrations, and the minimum ethanol production, performing typical butyrate-type fermentation. Since more acetate and less ethanol production mean that more NADH can be efficiently utilized for $\mathrm{H}_{2}$ production, the soluble metabolites profiles at $55^{\circ} \mathrm{C}$ was in accordance with better $\mathrm{H}_{2}$-producing performance in this case. At $37^{\circ} \mathrm{C}, 30^{\circ} \mathrm{C}$ and $70^{\circ} \mathrm{C}$, all the tests performed mixed acid fermentation, meaning that a large amount of NADH was used for liquid products other than $\mathrm{H}_{2}$, such as propionate [42]. In addition, we observed some formate production at $30{ }^{\circ} \mathrm{C}$, $55^{\circ} \mathrm{C}$, and $70{ }^{\circ} \mathrm{C}$, suggesting that some $\mathrm{H}_{2}$ might be generated via formate cleavage pathways in these cases [43].

\section{Microbial community structure}

In this study, PCR-DGGE and corresponding microbial diversity analysis were carried out to elucidate internal relationships between fermentation temperature and microbial community structure. Fig. 3 graphically displays different DGGE profiles of 16S rDNA fragments for microbial samples under different temperatures. For the fermentation process of corn stover hydrolyzate, microbial community structure was simple for the two seed sludges, especially for anaerobic granular sludge. The phenomenon might be mainly due to the selective enrichment of specific species capable of utilizing refractory sugars in stover hydrolyzate. In addition, it has been convinced that toxic byproducts in corn stover hydrolyzate can cause negative efforts on many species in seed sludges $[27,44]$. Under the situation, microbial community diversity unavoidably decreased with the elimination of non-
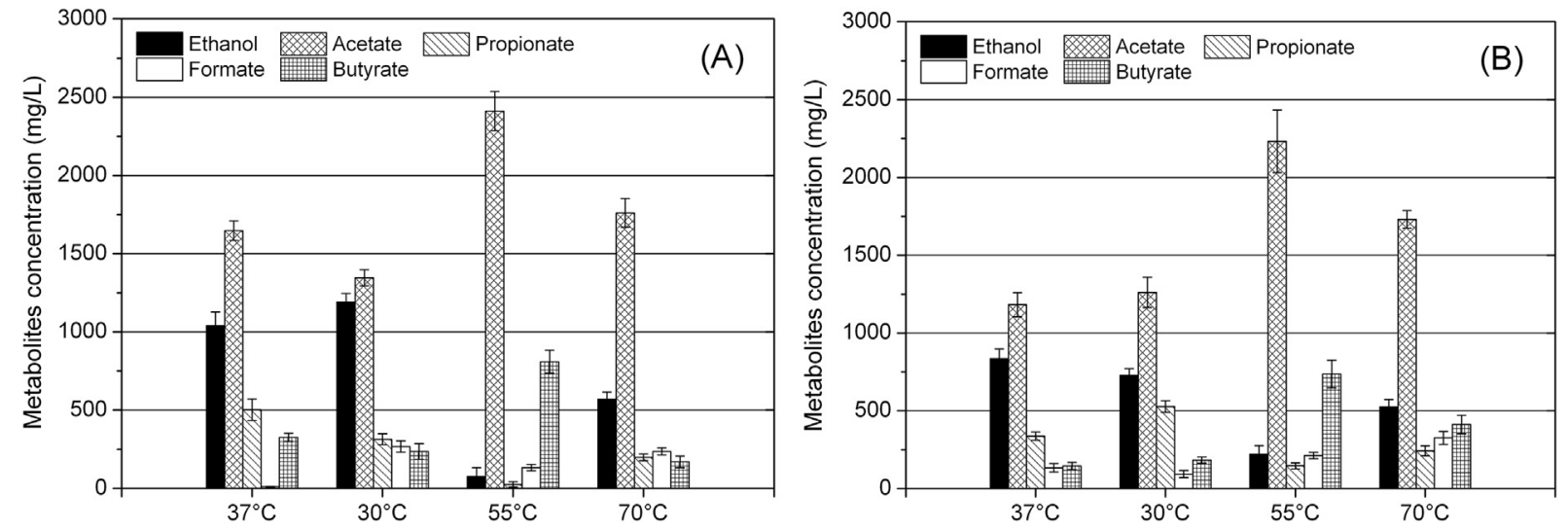

Fig. 2 - Soluble metabolites components under different fermentation temperatures. (A) activated sludge; (B) anaerobic granular sludge. 

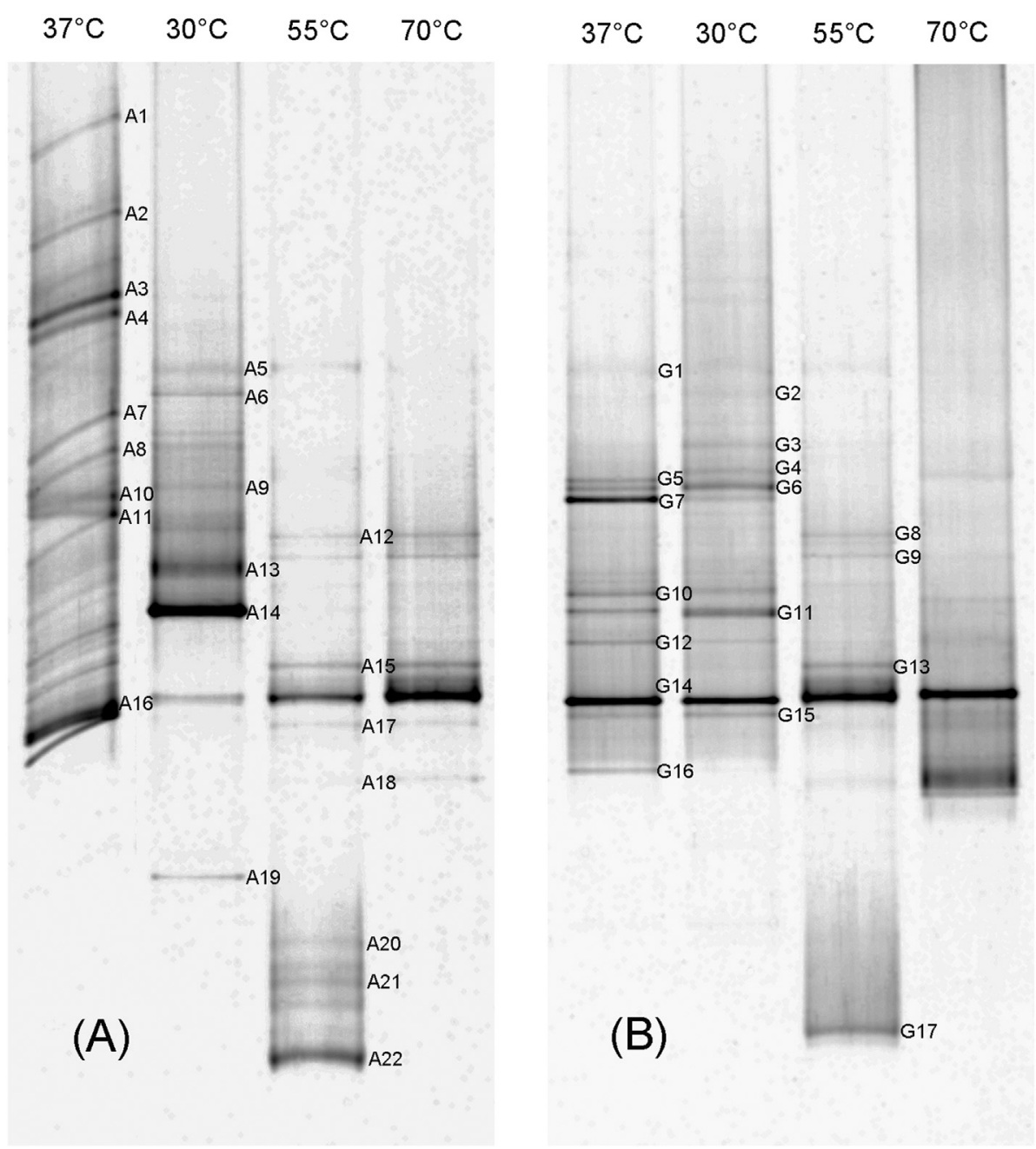

Fig. 3 - DGGE profiles of 16S rDNA gene fragments from samples under different fermentation temperatures. (A) activated sludge; (B) anaerobic granular sludge.

adaptable species and the enrichment of some functional microbes.

Fermentation temperature caused significant influences on microbial components. For activated sludge (Fig. 3A), fermentation process at $37^{\circ} \mathrm{C}$ and $30^{\circ} \mathrm{C}$ determined a complex microbial community with most species were present only with small quantities. However, microbial community structure at $55^{\circ} \mathrm{C}$ and $70{ }^{\circ} \mathrm{C}$ showed significant differences from that at mesophilic conditions, being characterized by selective enrichment of some specific species (band A16 and A22 at $55{ }^{\circ} \mathrm{C}$, band $\mathrm{A} 16$ at $70{ }^{\circ} \mathrm{C}$, etc.). For anaerobic granular sludge (Fig. 3B), microbial community diversity was relatively low under various temperatures. We assumed that the result might be attributed to simple microbial community structure in anaerobic granular sludge. In addition, microbial community was almost the same for $37^{\circ} \mathrm{C}$ and $30^{\circ} \mathrm{C}$, and was less similar to that at $55^{\circ} \mathrm{C}$ and $70^{\circ} \mathrm{C}$. The enrichment of a microbe (band G14) was found among various temperatures, suggesting that the strain might be well adapted to grow at a wide temperature range and act an important role due to its abundance.
Based on the digital recognition of dominant DGGE bands, number of bands, Shannon-Wiener diversity index, Simpson diversity index, and Pielou evenness index were calculated to address microbial community characteristics (Table 2). For the two seed sludges, more DGGE bands can be detected under mesophilic conditions ( 37 and $30{ }^{\circ} \mathrm{C}$ ), and number of bands significantly decreased under high temperatures (55 and $70{ }^{\circ} \mathrm{C}$ ). Shannon-Wiener diversity index and Simpson diversity index both performed a decreasing trend with the increase of fermentation temperature (except $30^{\circ} \mathrm{C}$ for activated sludge), indicating that the higher the fermentation temperature, the lower the microbial community diversity. The trend was also reported by previous studies $[22,45,46]$, and the reason might be possible susceptibility of many microbial species towards high temperatures. Pielou evenness index also showed similar variations with the other two diversity indexes. Low Pielou evenness index under high temperatures suggested that few species succeeded in dominating the microbial community. In these cases, high $\mathrm{H}_{2}$ yields might be in strong association with the behaviors of enriched species. Due to better $\mathrm{H}_{2}$-producing performances under high 
Table 2 - Microbial diversity parameters for $\mathrm{H}_{2}$ production under different fermentation temperatures.

\begin{tabular}{lccccc} 
Seed sludge & Temperature $\left({ }^{\circ} \mathrm{C}\right)$ & $\begin{array}{c}\text { Number } \\
\text { of bands }\end{array}$ & $\begin{array}{c}\text { Shannon-Wiener } \\
\text { diversity index }\end{array}$ & $\begin{array}{c}\text { Simpson } \\
\text { diversity index }\end{array}$ & $\begin{array}{c}\text { Pielou } \\
\text { evenness index }\end{array}$ \\
\hline Activated sludge & 37 & 14 & 2.334 & 0.868 & 0.706 \\
& 30 & 9 & 1.626 & 0.791 & 0.884 \\
& 55 & 9 & 1.838 & 0.525 & 0.740 \\
Anaerobic granular sludge & 70 & 6 & 1.122 & 0.808 & 0.836 \\
& 37 & 11 & 1.986 & 0.591 & 0.626 \\
& 30 & 11 & 1.920 & 0.560 & 0.618 \\
\hline
\end{tabular}

temperatures, the predominance of these species might be more beneficial for $\mathrm{H}_{2}$ production.

Prominent DGGE bands were sequenced and then aligned to determine their phylogenetic affiliation (Table 3 and Table 4). In the two tables, most bands (32 of 39) presented more than $97 \%$ similarities with known strains, indicating that they might belong to the same species. For the two seed sludges, facultative anaerobes were frequently detected in microbial community (activated sludge: Enterobacter spp. and Klebsiella spp.; anaerobic granular sludge: Klebsiella spp. and Citrobacter spp.). These facultative anaerobes might be partly responsible for $\mathrm{H}_{2}$ production by formate cleavage pathways [43]. For activated sludge, the microbes retrieved in large amounts were identified as Uncultured Enterobacter sp. clone LSSR31 (band A3), Uncultured Klebsiella sp. clone FC84 (band A14), and Bacillus sp. AB5283 (band A22). For anaerobic granular sludge, the abundant species were Uncultured Citrobacter sp. clone LR244 (band G7), Klebsiella oxytoca strain 2-30 (band G14), and Thermoanaerobacterium sp. PO-2009 (band G17). Due to large amounts of these species, they might be important participants for $\mathrm{H}_{2}$ production, substrate degradation, and soluble metabolites formation.

Based on the sequencing results, we found that the microbial community composition was similar for the two seed sludges, both performing the dominance of facultative anaerobes in microbial community. The high microbial community similarity for the two seed sludges might be due to the microbial responses during the utilization process of complex corn stover hydrolyzate. That is, the composition characteristics of corn stover hydrolyzate might cause similar selective effort on microbial species in the two seed sludges. The dominance of facultative anaerobes in microbial community could be explained as follows: since inoculum pretreatment was not applied in this study for maintaining original microbial components in the seed sludges, facultative anaerobes without spore-forming ability, such as Enterobacter spp., Klebsiella spp., and Citrobacter spp., had a good opportunity to survive from the harsh pretreatment conditions and then proliferated in the following fermentation process. Due to efficient substrate utilization and fast growth rate, facultative anaerobes rapidly dominated the microbial community during the fermentation process. Strict anaerobes, such as Clostridium spp., presented in small numbers and failed to compete with facultative anaerobes.

According to the $\mathrm{H}_{2}$-producing performances in Fig. 1, we could correspondingly recognize important functional consortium for $\mathrm{H}_{2}$ production. We found that high $\mathrm{H}_{2}$ yields were closely accompanied with the appearance of some strict and facultative anaerobes, which had been well investigated as efficient $\mathrm{H}_{2}$-producing microbes while using various complex substrates. For activated sludge, the facultative anaerobe

\begin{tabular}{|c|c|c|}
\hline Band & $\begin{array}{l}\text { The most similar sequence } \\
\text { (GenBank number) }\end{array}$ & Identity \\
\hline A1 & $\begin{array}{l}\text { Uncultured Enterobacter sp. clone } \\
\text { LR191 (HM597938.1) }\end{array}$ & $99 \%$ \\
\hline A2 & $\begin{array}{l}\text { Uncultured Pantoea sp. clone } \\
\text { LSSR82 (HM597952.1) }\end{array}$ & $99 \%$ \\
\hline A3 & $\begin{array}{l}\text { Uncultured Enterobacter sp. clone } \\
\text { LSSR31 (HM597964.1) }\end{array}$ & $99 \%$ \\
\hline A4 & $\begin{array}{l}\text { Enterobacter ludwigii isolate B2 } \\
\text { (FR752805.1) }\end{array}$ & $99 \%$ \\
\hline A5 & $\begin{array}{l}\text { Enterobacter asburiae strain YMC/ } \\
\text { KN/07/05 (HQ215202.1) }\end{array}$ & $96 \%$ \\
\hline A6 & Klebsiella sp. bk_20 (HQ538674.1) & $99 \%$ \\
\hline A7 & Enterobacter sp. RP1p (EF585402.1) & $100 \%$ \\
\hline A8 & $\begin{array}{l}\text { Leclercia adecarboxylata strain C107 } \\
\text { (HQ407282.1) }\end{array}$ & $99 \%$ \\
\hline A9 & $\begin{array}{l}\text { Citrobacter werkmanii strain 2C1-9 } \\
\text { (GU169032.1) }\end{array}$ & $98 \%$ \\
\hline A10 & $\begin{array}{l}\text { Uncultured Citrobacter sp. clone } \\
\text { LR244 (HM597945.1) }\end{array}$ & $99 \%$ \\
\hline A11 & $\begin{array}{l}\text { Enterobacter aerogenes strain LCR83 } \\
\text { (FJ976592.1) }\end{array}$ & $99 \%$ \\
\hline A12 & $\begin{array}{l}\text { uncultured gamma } \\
\text { proteobacterium clone LL1 } \\
\text { (AJ581650.1) }\end{array}$ & $100 \%$ \\
\hline A13 & $\begin{array}{l}\text { Uncultured Serratia sp. clone } \\
\text { F7may2.72 (GQ416511.1) }\end{array}$ & $100 \%$ \\
\hline A14 & $\begin{array}{l}\text { Uncultured Klebsiella sp. clone FC84 } \\
\text { (HM598006.1) }\end{array}$ & $100 \%$ \\
\hline A15 & $\begin{array}{l}\text { Salmonella paratyphi strain A6 } \\
\text { (EU118081.1) }\end{array}$ & $99 \%$ \\
\hline A16 & $\begin{array}{l}\text { Klebsiella oxytoca strain 2-30 } \\
\text { (GU586149.1) }\end{array}$ & $100 \%$ \\
\hline A17 & $\begin{array}{l}\text { Uncultured Pectobacterium sp. clone } \\
\text { FC81 (HM598005.1) }\end{array}$ & $100 \%$ \\
\hline A18 & $\begin{array}{l}\text { Leuconostoc pseudomesenteroides } \\
\text { strain 1-2 (HQ825325.1) }\end{array}$ & $92 \%$ \\
\hline A19 & $\begin{array}{l}\text { Escherichia vulneris strain M3 } \\
\text { (HQ259947.1) }\end{array}$ & $100 \%$ \\
\hline A20 & $\begin{array}{l}\text { Uncultured Lentisphaerae bacterium } \\
\text { 283ZH04 (GQ451984.1) }\end{array}$ & $95 \%$ \\
\hline A21 & $\begin{array}{l}\text { Mycobacteriaceae bacterium WR054 } \\
\text { (AB298730.2) }\end{array}$ & $94 \%$ \\
\hline A22 & Bacillus sp. AB5283 (GU366039.1) & $99 \%$ \\
\hline
\end{tabular}


Table 4 - Phylogenetic affiliation of 16S rDNA gene sequences from DGGE bands of anaerobic granular sludge.

\begin{tabular}{|c|c|c|}
\hline Band & $\begin{array}{l}\text { The most similar sequence } \\
\text { (GenBank number) }\end{array}$ & Identity \\
\hline G1 & $\begin{array}{l}\text { Enterobacter asburiae strain YMC/ } \\
\text { KN/07/05 (HQ215202.1) }\end{array}$ & $96 \%$ \\
\hline G2 & Klebsiella sp. bk_20 (HQ538674.1) & $99 \%$ \\
\hline G3 & $\begin{array}{l}\text { Leclercia adecarboxylata strain C107 } \\
\text { (HQ407282.1) }\end{array}$ & $99 \%$ \\
\hline G4 & $\begin{array}{l}\text { Citrobacter freundii strain FUA1259 } \\
\text { (HQ694731.1) }\end{array}$ & $100 \%$ \\
\hline G5 & $\begin{array}{l}\text { Uncultured Klebsiella sp. clone } \\
\text { rot468 (EF645654.1) }\end{array}$ & $99 \%$ \\
\hline G6 & $\begin{array}{l}\text { Citrobacter werkmanii strain 2C1-9 } \\
\text { (GU169032.1) }\end{array}$ & $98 \%$ \\
\hline G7 & $\begin{array}{l}\text { Uncultured Citrobacter sp. clone } \\
\text { LR244 (HM597945.1) }\end{array}$ & $99 \%$ \\
\hline G8 & $\begin{array}{l}\text { uncultured gamma } \\
\text { proteobacterium clone LL1 } \\
\text { (AJ581650.1) }\end{array}$ & $100 \%$ \\
\hline G9 & $\begin{array}{l}\text { Uncultured Serratia sp. clone } \\
\text { F7may2.72 (GQ416511.1) }\end{array}$ & $100 \%$ \\
\hline G10 & Kluyvera sp. bk_32 (HQ538675.1) & $100 \%$ \\
\hline G11 & $\begin{array}{l}\text { Uncultured Klebsiella sp. clone FC84 } \\
\text { (HM598006.1) }\end{array}$ & $100 \%$ \\
\hline G12 & $\begin{array}{l}\text { Clostridium bifermentans strain MKA } \\
5 \text { (HQ013321.1) }\end{array}$ & $96 \%$ \\
\hline G13 & $\begin{array}{l}\text { Salmonella paratyphi strain A6 } \\
\text { (EU118081.1) }\end{array}$ & $99 \%$ \\
\hline G14 & $\begin{array}{l}\text { Klebsiella oxytoca strain 2-30 } \\
\text { (GU586149.1) }\end{array}$ & $100 \%$ \\
\hline G15 & $\begin{array}{l}\text { Uncultured Pectobacterium sp. clone } \\
\text { FC81 (HM598005.1) }\end{array}$ & $100 \%$ \\
\hline G16 & $\begin{array}{l}\text { Leuconostoc pseudomesenteroides } \\
\text { strain 1-2 (HQ825325.1) }\end{array}$ & $92 \%$ \\
\hline G17 & $\begin{array}{l}\text { Thermoanaerobacterium sp. PO-2009 } \\
\text { (FM999998.1) }\end{array}$ & $100 \%$ \\
\hline
\end{tabular}

Bacillus sp. AB5283 presented large amounts at fermentation temperature of $55{ }^{\circ} \mathrm{C}$. In a previous work, Kotay et al. [47] isolated Bacillus coagulans strain IIT-BT S1 from digested activated sewage sludge, and the strain reached a high $\mathrm{H}_{2}$ yield by using glucose. It suggested that Bacillus sp. AB5283 might be a key $\mathrm{H}_{2}$ producer with activated sludge as the seed sludge. For anaerobic granular sludge, the predominance of Thermoanaerobacterium sp. PO-2009 was observed at $55{ }^{\circ} \mathrm{C}$, and the same strain was previously detected by Karadag et al. [46] while performing optimal $\mathrm{H}_{2}$ production at $60^{\circ} \mathrm{C}$. It has been reported that many efficient $\mathrm{H}_{2}$-producing strains of Thermoanaerobacterium spp. have the optimal growth temperature around $60{ }^{\circ} \mathrm{C}$, and most of them were capable of degrading complex carbohydrates along with abundant $\mathrm{H}_{2}$ emission $[13,48]$. Hence, with anaerobic granular sludge as the seed sludge, Thermoanaerobacterium sp. PO-2009 might be mainly responsible for the better $\mathrm{H}_{2}$-producing performance under thermophilic condition $\left(55^{\circ} \mathrm{C}\right)$.

\section{Overall performances}

Table 5 shows overall performances for $\mathrm{OD}_{600}$, final $\mathrm{pH}$, substrate utilization, $\mathrm{H}_{2}$ yield, and average $\mathrm{H}_{2}$ production rate. Among various temperatures, the fermentation process at $55{ }^{\circ} \mathrm{C}$ produced less biomass with the $\mathrm{OD}_{600}$ of 0.71 for activated sludge and 0.75 for anaerobic granular sludge, suggesting that more substrate can be efficiently utilized for producing $\mathrm{H}_{2}$ rather than biosynthesis. The fermentation process at $55^{\circ} \mathrm{C}$ also resulted in the lowest final pH (activated sludge: 4.56; anaerobic granular sludge: 4.09), which can be attributed to more acetate production in these cases. The substrate utilization under different temperatures was all around $90 \%$, indicating that there might still existed some complex compounds in corn stover hydrolyzate nonbiodegradable for microbes under various temperatures. For the two typical seed sludges, the fermentation at $55^{\circ} \mathrm{C}$ both reached the highest $\mathrm{H}_{2}$ yield and average $\mathrm{H}_{2}$ production rate (activated sludge: $6.08 \mathrm{mmol}-\mathrm{H}_{2} /$ g-utilized sugar and $0.98 \mathrm{mmol}-\mathrm{H}_{2} /(\mathrm{L} \cdot \mathrm{h})$; anaerobic granular sludge: $7.74 \mathrm{mmol}-\mathrm{H}_{2} /$

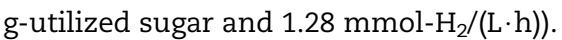

The maximum $\mathrm{H}_{2}$ yields and average $\mathrm{H}_{2}$ production rates in this study were compared with previous studies (Table 6). According to the table, many studies were carried out under mesophilic conditions $\left(35-37^{\circ} \mathrm{C}\right.$ ) for $\mathrm{H}_{2}$ production from straw hydrolyzate. While comparing $\mathrm{H}_{2}$ yields under different temperatures, thermophilic $\left(55^{\circ} \mathrm{C}\right)$ and extreme thermophilic $\left(70{ }^{\circ} \mathrm{C}\right)$ conditions led to relatively higher $\mathrm{H}_{2}$ yields than mesophilic conditions, suggesting that thermophilic microbial community might be favorable for $\mathrm{H}_{2}$ production by utilizing complex hydrolyzate. In this study, the maximum $\mathrm{H}_{2}$ yields were slightly lower than those of comparable results under thermophilic and extreme-thermophilic conditions. The reason might be mainly due to the dominance of facultative anaerobes (Enterobacter spp., etc.) in microbial community,

\section{Table 5 - Overall performances for $\mathrm{OD}_{600}$, final $\mathrm{pH}$, substrate utilization, $\mathrm{H}_{2}$ yield, and average $\mathrm{H}_{2}$ production rate.}

\begin{tabular}{|c|c|c|c|c|c|c|}
\hline Seed sludge & Temperature $\left({ }^{\circ} \mathrm{C}\right)$ & $\mathrm{OD}_{600}$ & inal $\mathrm{pH}$ & $\begin{array}{l}\text { Substrate } \\
\text { utilization }\end{array}$ & $\begin{array}{c}\mathrm{H}_{2} \text { yield } \\
\text { (mmol- } \mathrm{H}_{2} / \mathrm{g} \text { - utilized sugar) }\end{array}$ & $\begin{array}{c}\text { Average } \mathrm{H}_{2} \text { production rate } \\
\left(\mathrm{mmol}-\mathrm{H}_{2} /(\mathrm{L} \cdot \mathrm{h})\right)\end{array}$ \\
\hline \multirow[t]{4}{*}{ Activated sludge } & 37 & 1.04 & 5.29 & $91.3 \%$ & 2.70 & 0.48 \\
\hline & 30 & 1.49 & 5.48 & $92.8 \%$ & 2.65 & 0.51 \\
\hline & 55 & 0.71 & 4.56 & $89.8 \%$ & 6.08 & 0.98 \\
\hline & 70 & 0.78 & 4.99 & $86.4 \%$ & 4.10 & 0.63 \\
\hline \multirow[t]{4}{*}{ Anaerobic granular sludge } & 37 & 1.14 & 5.53 & $87.7 \%$ & 2.24 & 0.82 \\
\hline & 30 & 1.12 & 5.36 & $90.2 \%$ & 2.43 & 0.91 \\
\hline & 55 & 0.75 & 4.09 & $92.4 \%$ & 7.74 & 1.28 \\
\hline & 70 & 1.32 & 4.78 & $89.3 \%$ & 4.58 & 0.73 \\
\hline
\end{tabular}

Values represent the means of three incubations. 
Table 6 - Comparison of $\mathrm{H}_{2}$ yield and average $\mathrm{H}_{2}$ production rate with previous studies.

\begin{tabular}{|c|c|c|c|c|c|}
\hline Inoculum & Substrate & $\begin{array}{l}\text { Temp. } \\
\left({ }^{\circ} \mathrm{C}\right)\end{array}$ & $\begin{array}{l}\mathrm{H}_{2} \text { yield (mmol- } \mathrm{H}_{2} / g- \\
\text { utilized sugar) }\end{array}$ & $\begin{array}{l}\text { Average } \mathrm{H}_{2} \text { production rate } \\
\left(\mathrm{mmol}-\mathrm{H}_{2} /(\mathrm{L} \cdot \mathrm{h})\right)\end{array}$ & Ref. \\
\hline Cow dung compost & Wheat straw hydrolyzate & 36 & 3.04 & 0.60 & [49] \\
\hline Dairy manure & Corncob hydrolyzate & 36 & 4.82 & 1.88 & [50] \\
\hline Activated sludge & Rice straw hydrolyzate & 37 & 5.67 & n.d. & [51] \\
\hline $\begin{array}{l}\text { Anaerobically digested } \\
\text { sludge }\end{array}$ & Rice straw hydrolyzate & 35 & 1.25 & n.d. & [52] \\
\hline $\begin{array}{l}\text { Sludge from an anaerobic } \\
\text { digester }\end{array}$ & Wheat straw hydrolyzate & 37 & 3.86 & n.d. & [53] \\
\hline Anaerobic digester Sludge & Wheat straw hydrolyzate & 35 & 2.63 & n.d. & [54] \\
\hline $\begin{array}{l}\text { Sludge from a local } \\
\text { winery }\end{array}$ & Corn stover hydrolyzate & 55 & 8.13 & 0.38 & [55] \\
\hline Anaerobic sludge & Ground wheat hydrolyzate & 55 & 8.54 & 0.66 & [24] \\
\hline Granular sludge & Wheat straw hydrolyzate & 70 & 9.46 & 1.53 & [56] \\
\hline Activated sludge & Corn stover hydrolysate & 55 & 6.08 & 0.98 & This study \\
\hline $\begin{array}{l}\text { Anaerobic granular } \\
\text { sludge }\end{array}$ & Corn stover hydrolysate & 55 & 7.74 & 1.28 & This study \\
\hline
\end{tabular}

which always have relatively lower $\mathrm{H}_{2}$-producing ability than strict microbes (Clostridium spp., etc.).

\section{Conclusions}

With activated sludge and anaerobic granular sludge as the seed sludge, mesophilic (37 and $30^{\circ} \mathrm{C}$ ), thermophilic $\left(55^{\circ} \mathrm{C}\right.$ ) and extreme thermophilic $\left(70^{\circ} \mathrm{C}\right)$ conditions were compared for their effectiveness in improving $\mathrm{H}_{2}$ production from corn stover hydrolyzate. Experimental results indicated that fermentation temperature caused similar effects on $\mathrm{H}_{2}$ production for the two seed sludges with the optimum $\mathrm{H}_{2}$ yields both achieved at $55^{\circ} \mathrm{C}$ (activated sludge: $6.08 \mathrm{mmol}-\mathrm{H}_{2} /$ g-uti-

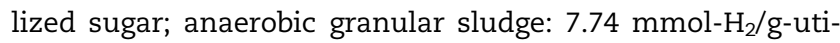
lized sugar). $\mathrm{H}_{2}$ production at $70^{\circ} \mathrm{C}$ was remarkably less than at $55{ }^{\circ} \mathrm{C}$, and fermentation processes at $37^{\circ} \mathrm{C}$ and $30{ }^{\circ} \mathrm{C}$ resulted in even lower $\mathrm{H}_{2}$ production. PCR-DGGE and corresponding biodiversity analysis indicated that fermentation temperature caused significant influences on microbial components. Generally, the higher the fermentation temperature, the lower the microbial community diversity. For the two seed sludges, facultative anaerobes, such as Enterobacter spp., Klebsiella spp., and Citrobacter spp., were dominant in microbial community. For the fermentation at $55^{\circ} \mathrm{C}$, Bacillus sp. AB5283 and Thermoanaerobacterium sp. PO-2009 might be key $\mathrm{H}_{2}$ producers in activated sludge and anaerobic granular sludge, respectively. Among various temperatures, thermophilic condition $\left(55^{\circ} \mathrm{C}\right)$ was preferable for biohydrogen production from corn stover hydrolyzate.

\section{Acknowledgments}

This research was financially supported by the National Natural Science Foundation of China (Grant No. 51178140, 51009039 and 51179037), the funding from Project 50821002 (National Creative Research Groups) by National Nature
Science Foundation of China, and the Centre College Primary Scientific Research Item Funds (HEUCFZ1103).

[1] Lin CY, Lay CH, Sen B, Chu CY, Kumar G, Chen CC, et al. Fermentative hydrogen production from wastewaters: a review and prognosis. Int J Hydrogen Energy 2012;37:15632-42.

[2] Wong YM, Wu TY, Juan JC. A review of dark fermentative hydrogen production from biodegradable municipal waste fractions. Renew Sust Energ Rev 2014;34:471-82.

[3] Hawkes FR, Hussy I, Kyazze G, Dinsdale R, Hawkes DL. Continuous dark fermentative hydrogen production by mesophilic microflora: principles and progress. Int J Hydrogen Energy 2007;32:172-84.

[4] Dutta S. A review on production, storage of hydrogen and its utilization as an energy resource. J Ind Eng Chem 2014;20:1148-56.

[5] Gioannis GD, Muntoni A, Polettini A, Pomi R. A review of dark fermentative hydrogen production from biodegradable municipal waste fractions. Waste Manage 2013;33:1345-61.

[6] Varrone C, Liberatore R, Crescenzi T, Izzo G, Wang A. The valorization of glycerol: economic assessment of an innovative process for the bioconversion of crude glycerol into ethanol and hydrogen. Appl Energy 2013;105:349-57.

[7] Han W, Wang B, Zhou Y, Wang DX, Wang Y, Yue LR, et al. Fermentative hydrogen production from molasses wastewater in a continuous mixed immobilized sludge reactor. Bioresour Technol 2012;110:219-23.

[8] Shi Y, Zhao XT, Cao P, Hu YY, Zhang L, Jia Y, et al. Hydrogen bio-production through anaerobic microorganism fermentation using kitchen wastes as substrate. Biotechnol Lett 2009;31:1327-33.

[9] Varrone C, Giussani B, Izzo G, Massini G, Marone A, Signorini A, et al. Statistical optimization of biohydrogen and ethanol production from crude glycerol by microbial mixed culture. Int J Hydrogen Energy 2012;37:16479-88.

[10] Ho KL, Lee DJ, Su A, Chang JS. Biohydrogen from lignocellulosic feedstock via one-step process. Int J Hydrogen Energy 2012;37:15569-74. 
[11] Nissila ME, Lay CH, Puhakka JA. Dark fermentative hydrogen production from lignocellulosic hydrolyzates - a review. Biomass Bioenerg 2014;67:145-9.

[12] Cheng CL, Lo YC, Lee KS, Lee DJ, Lin CY, Chang JS. Biohydrogen production from lignocellulosic feedstock. Bioresour Technol 2011;102:8514-23.

[13] Ren NQ, Cao GL, Wang AJ, Lee DJ, Guo WQ, Zhu YH. Dark fermentation of xylose and glucose mix using isolated Thermoanaerobacterium thermosaccharolyticum W16. Int J Hydrogen Energy 2008;33:6124-32.

[14] Chu CY, Tung L, Lin CY. Effect of substrate concentration and $\mathrm{pH}$ on biohydrogen production kinetics from food industry wastewater by mixed culture. Int J Hydrogen Energy 2013;38:15849-55.

[15] Argun H, Kargi F, Kapdan IK, Oztekin R. Batch dark fermentation of powdered wheat starch to hydrogen gas: effects of the initial substrate and biomass concentrations. Int J Hydrogen Energy 2008;33:6109-15.

[16] Kothari R, Singh DP, Tyagi VV, Tyagi SK. Fermentative hydrogen production - an alternative clean energy source. Renew Sust Energ Rev 2012;16:2337-46.

[17] Lee KS, Lin PJ, Chang JS. Temperature effects on biohydrogen production in a granular sludge bed induced by activated carbon carriers. Int J Hydrogen Energy 2006;31:465-72.

[18] Cavinato C, Bolzonella D, Fatone F, Cecchi F, Pavan P. Optimization of two-phase thermophilic anaerobic digestion of biowaste for hydrogen and methane production through reject water recirculation. Bioresour Technol 2011;102:8605-11.

[19] Shanmugam SR, Chaganti SR, Lalman JA, Heath DD. Statistical optimization of conditions for minimum $\mathrm{H}_{2}$ consumption in mixed anaerobic cultures: effect on homoacetogenesis and methanogenesis. Int J Hydrogen Energy 2014;39:15433-45.

[20] Ren NQ, Wang AJ, Cao GL, Xu JF, Gao LF. Bioconversion of lignocellulosic biomass to hydrogen: potential and challenges. Biotechnol Adv 2009;27:1051-60.

[21] Yossan S, O-Thong S, Prasertsan P. Effect of initial pH, nutrients and temperature on hydrogen production from palm oil mill effluent using thermotolerant consortia and corresponding microbial communities. Int J Hydrogen Energy 2012;37:13806-14.

[22] Shi XQ Kim DH, Shin HS, Jung KW. Effect of temperature on continuous fermentative hydrogen production from Laminaria japonica by anaerobic mixed cultures. Bioresour Technol 2013;144:225-31.

[23] Gilroyed BH, Chang C, Chu A, Hao XY. Effect of temperature on anaerobic fermentative hydrogen gas production from feedlot cattle manure using mixed microflora. Int J Hydrogen Energy 2008;33:4301-8.

[24] Cakir A, Ozmihci S, Kargi F. Comparison of bio-hydrogen production from hydrolyzed wheat starch by mesophilic and thermophilic dark fermentation. Int J Hydrogen Energy 2010;35:13214-8.

[25] Gadow SI, Jiang H, Watanabe R, Li YY. Effect of temperature and temperature shock on the stability of continuous cellulosic-hydrogen fermentation. Bioresour Technol 2013;142:304-11.

[26] Michel D, Gilles KA, Hamilton JK, Rebers PA, Smith F. Colorimetric method for determination of sugars and related substances. Anal Chem 1956;28:350-6.

[27] Cao GL, Ren NQ, Wang AJ, Guo WQ Xu JF, Liu BF. Effect of lignocellulose-derived inhibitors on growth and hydrogen production by Thermoanaerobacterium thermosaccharolyticum W16. Int J Hydrogen Energy 2010;35:13475-80.

[28] Wang XH, Zhang K, Ren NQ Li N, Ren LJ. Monitoring microbial community structure and succession of an $\mathrm{A} / \mathrm{O}$
SBR during start-up period using PCR-DGGE. J Environ Sci 2009;21:223-8.

[29] Nuebel U, Engelen B, Felske A, Snaidr J, Wieshuber A, Amann RI, et al. Sequence heterogeneities of genes encoding 16S rRNAs in Paenibacillus Polymyxa detected by temperature gradient gel electrophoresis. J Bacteriol 1996;178:5636-43.

[30] Zouache K, Raharimalala FN, Raquin V, Tran-Van V, Raveloson LHR, Ravelonandro P, et al. Bacterial diversity of field-caught mosquitoes, Aedes albopictus and Aedes aegypti, from different geographic regions of Madagascar. FEMS Microbiol Ecol 2011;75:377-89.

[31] Zhang K, Ren NQ, Cao GL, Wang AJ. Biohydrogen production behavior of moderately thermophile Thermoanaerobacterium thermosaccharolyticum W16 under different gas-phase conditions. Int J Hydrogen Energy 2011;36:14041-8.

[32] Hernandez JE, Edyvean RGJ. Inhibition of biogas production and biodegradability by substituted phenolic compounds in anaerobic sludge. J Hazard Mater 2008;160:20-8.

[33] Kumar G, Lin CY. Bioconversion of de-oiled Jatropha Waste (DJW) to hydrogen and methane gas by anaerobic fermentation: influence of substrate concentration, temperature and pH. Int J Hydrogen Energy 2013;38:63-72.

[34] Akutsu Y, Li YY, Harada H, Yu HQ. Effects of temperature and substrate concentration on biological hydrogen production from starch. Int J Hydrogen Energy 2009;34:2558-66.

[35] Yokoyama H, Waki M, Moriya N, Yasuda T, Tanaka Y, Haga K. Effect of fermentation temperature on hydrogen production from cow waste slurry by using anaerobic microflora within the slurry. Appl Microbiol Biotechnol 2007;74:474-83.

[36] Kongjan P, Min B, Angelidaki I. Biohydrogen production from xylose at extreme thermophilic temperatures $\left(70^{\circ} \mathrm{C}\right)$ by mixed culture fermentation. Water Res 2009;43:1414-24.

[37] Liu DW, Zeng RJ, Angelidakia I. Enrichment and adaptation of extreme- thermophilic $\left(70^{\circ} \mathrm{C}\right)$ hydrogen producing bacteria to organic household solid waste by repeated batch cultivation. Int J Hydrogen Energy 2008;33:6492-7.

[38] Zhao CX, O-Thong S, Karakashev D, Angelidaki I, Lu WJ, Wang HT. High yield simultaneous hydrogen and ethanol production under extreme-thermophilic $\left(70^{\circ} \mathrm{C}\right)$ mixed culture environment. Int J Hydrogen Energy 2009;34:5657-65.

[39] Han W, Wang ZQ, Chen H, Yao X, Li YF. Simultaneous biohydrogen and bioethanol production from anaerobic fermentation with immobilized sludge. J Biomed Biotechnol 2011;2011:1-5.

[40] Zhang K, Ren NQ, Guo CH, Wang AJ, Cao GL. Effects of various pretreatment methods on mixed microflora to enhance biohydrogen production from corn stover hydrolysate. J Environ Sci 2011;23:1929-36.

[41] Zhang K, Ren NQ, Wang AJ. Enhanced biohydrogen production from corn stover hydrolyzate by pretreatment of two typical seed sludges. Int J Hydrogen Energy 2014;39:14653-62.

[42] Lazaro CZ, Perna V, Etchebehere C, Varesche MBA. Sugarcane vinasse as substrate for fermentative hydrogen production: the effects of temperature and substrate concentration. Int J Hydrogen Energy 2014;39:6407-18.

[43] Das D, Veziroglu TN. Hydrogen production by biological processes: a survey of literature. Int J Hydrogen Energy 2001;26:13-28.

[44] Monlau F, Sambusiti C, Barakat A, Quéméneur M, Trably E, Steyer JP, et al. Do furanic and phenolic compounds of lignocellulosic and algae biomass hydrolyzate inhibit anaerobic mixed cultures? A comprehensive review. Biotechnol Adv 2014;32:934-51.

[45] Carillo P, Carotenuto C, Cristofaro FD, Kafantaris I, Lubritto C, Minale M, et al. DGGE analysis of buffalo manure eubacteria 
for hydrogen production: effect of $\mathrm{pH}$, temperature and pretreatments. Mol Biol Rep 2012;39:10193-200.

[46] Karadag D, Puhakka JA. Effect of changing temperature on anaerobic hydrogen production and microbial community composition in an open-mixed culture bioreactor. Int J Hydrogen Energy 2010;35:10954-9.

[47] Kotay SM, Das D. Microbial hydrogen production with Bacillus coagulans IIT-BT S1 isolated from anaerobic sewage sludge. Bioresour Technol 2007;98:1183-90.

[48] Khamtib S, Reungsang A. Biohydrogen production from xylose by Thermoanaerobacterium thermosaccharolyticum KKU19 isolated from hot spring sediment. Int J Hydrogen Energy 2012;37:12219-28.

[49] Fan YT, Zhang YH, Zhang SF, Hou HW, Ren BZ. Efficient conversion of wheat straw wastes into biohydrogen gas by cow dung compost. Bioresour Technol 2006;97:500-5.

[50] Pan CM, Zhang SF, Fan YT, Hou HW. Bioconversion of corncob to hydrogen using anaerobic mixed microflora. Int $J$ Hydrogen Energy 2010;35:2663-9.

[51] Liu CM, Wu SY, Chu CY, Chou YP. Biohydrogen production from rice straw hydrolyzate in a continuously external circulating bioreactor. Int J Hydrogen Energy 2014;39:19317-22.

[52] He LL, Huang H, Lei ZF, Liu CG, Zhang ZY. Enhanced hydrogen production from anaerobic fermentation of rice straw pretreated by hydrothermal technology. Bioresour Technol 2014;171:145-51.

[53] Lara-Vazquez AR, Sanchez A, Valdez-Vazquez I. Hydration treatments increase the biodegradability of native wheat straw for hydrogen production by a microbial consortium. Int J Hydrogen Energy 2014;39:19899-904.

[54] Reilly M, Dinsdale R, Guwy A. Mesophilic biohydrogen production from calcium hydroxide treated wheat straw. Int J Hydrogen Energy 2014;39:16891-901.

[55] Liu CZ, Cheng XY. Improved hydrogen production via thermophilic fermentation of corn stover by microwaveassisted acid pretreatment. Int J Hydrogen Energy 2010;35:8945-52.

[56] Kongjan P, Angelidaki I. Extreme thermophilic biohydrogen production from wheat straw hydrolysate using mixed culture fermentation: effect of reactor configuration. Bioresour Technol 2010;101:7789-96. 